\title{
Presynaptic and Postsynaptic Mechanisms of a Novel Form of Homosynaptic Potentiation at Aplysia Sensory-Motor Neuron Synapses
}

\author{
Iksung Jin ${ }^{1}$ and Robert D. Hawkins ${ }^{1,2}$ \\ ${ }^{1}$ Center for Neurobiology and Behavior, Columbia University, and ${ }^{2}$ New York State Psychiatric Institute, New York, New York 10032
}

\begin{abstract}
Previous studies have shown that homosynaptic potentiation produced by rather mild tetanic stimulation $(20 \mathrm{~Hz}, 2 \mathrm{sec})$ at Aplysia sensory-motor neuron synapses in isolated cell culture involves both presynaptic and postsynaptic $\mathrm{Ca}^{2+}$ (Bao et al., 1997). We have now investigated the sources of $\mathrm{Ca}^{2+}$ and some of its downstream targets. Although the potentiation lasts $>30 \mathrm{~min}$, it does not require $\mathrm{Ca}^{2+}$ influx through either NMDA receptor channels or L-type $\mathrm{Ca}^{2+}$ channels. Rather, the potentiation involves metabotropic receptors and intracellular $\mathrm{Ca}^{2+}$ release from both postsynaptic $\mathrm{IP}_{3}$-sensitive and presynaptic ryanodine-sensitive stores. In addition, it involves protein kinases, including both presynaptic and postsynaptic CamKII and probably MAP kinase. Finally, it does not require transsynaptic signaling by nitric oxide but it may involve AMPA receptor insertion. The potentiation, thus, shares components of the mechanisms of post-tetanic potentiation, NMDA- and mGluR-dependent long-term potentiation, and even long-term depression, but is not identical to any of them. These results are consistent with the more general idea that there is a molecular alphabet of basic components that can be combined in various ways to create novel as well as known types of plasticity.
\end{abstract}

Key words: Aplysia; potentiation; presynaptic; postsynaptic; $\mathrm{Ca}^{2+}$ stores; CamKII

\section{Introduction}

Synaptic plasticity occurs in a number of different types including homosynaptic and heterosynaptic, facilitatory and inhibitory, associative and nonassociative, and short term and long term. An important unresolved question has been whether these different types of plasticity involve fundamentally different mechanisms, or whether they share an alphabet of basic mechanisms that are combined in different ways. Aplysia sensory-motor neuron synapses in isolated cell culture provide a good preparation to address this question, because they exhibit all of the different types of plasticity at one synapse (Rayport and Schacher, 1986; Montarolo et al., 1986, 1988; Schacher et al., 1990; Eliot et al., 1994a,b; Lin and Glanzman, 1994a,b; Bao et al., 1997, 1998; Schacher et al., 1997). In addition, they have a number of technical advantages for examining the mechanisms of plasticity. First, the neurons are identified individuals with known behavioral functions. Second, because there are no other neurons in the dish and they do not form autapses, one can unambiguously distinguish between homosynaptic and heterosynaptic effects and also know the source of spontaneous miniature EPSPs with certainty. Furthermore, because both sides of the synapses are accessible to substances

Received April 15, 2003; revised June 18, 2003; accepted June 18, 2003.

This work was supported by National Institutes of Mental Health Grant MH26212. We thank E. R. Kandel and S. A. Siegelbaum for comments and B. Robertson for typing this manuscript.

Correspondence should be addressed to Dr. Robert Hawkins, Center for Neurobiology and Behavior, Columbia University, 1051 Riverside Drive, New York, NY 10032. E-mail: rdh1@columbia.edu.

Copyright $\odot 2003$ Society for Neuroscience $\quad$ 0270-6474/03/237288-10\$15.00/0 injected into the cell bodies, one can manipulate presynaptic as well as postsynaptic mechanisms.

For these reasons, we and others have used this preparation to study mechanisms of a variety of types of plasticity, including potentiation produced by rather mild $(20 \mathrm{~Hz}, 2 \mathrm{sec})$ tetanization of the presynaptic neuron. The behavioral relevance of this potentiation is still unclear, but when the tetanus is paired temporally with serotonin, the two stimuli act synergistically to create an associative mechanism, activity-dependent presynaptic facilitation, that is thought to contribute to classical conditioning in Aplysia (Eliot et al., 1994a; Bao et al., 1998; Antonov et al., 2003). Thus, understanding mechanisms of the potentiation may be important for understanding mechanisms of the more complex associative effects.

Previous studies have revealed that the potentiation involves aspects of the mechanisms of both post-tetanic potentiation (PTP) and long-term potentiation (LTP), including dependence on both presynaptic and postsynaptic $\mathrm{Ca}^{2+}$ (Eliot et al., 1994b; Bao et al., 1997). We have now explored other molecules that might be involved, focusing on the sources of $\mathrm{Ca}^{2+}$ and some of its downstream targets. Our results indicate that the potentiation shares additional aspects of the mechanisms of PTP, both NMDA-dependent and mGluR-dependent LTP, and even longterm depression (LTD), but is not identical to any of them. It is, therefore, a novel form of plasticity that we now refer to simply as homosynaptic potentiation. These results are also consistent with the more general idea that different types of plasticity do not involve fundamentally different mechanisms, but rather share an alphabet of basic mechanisms that can be combined 

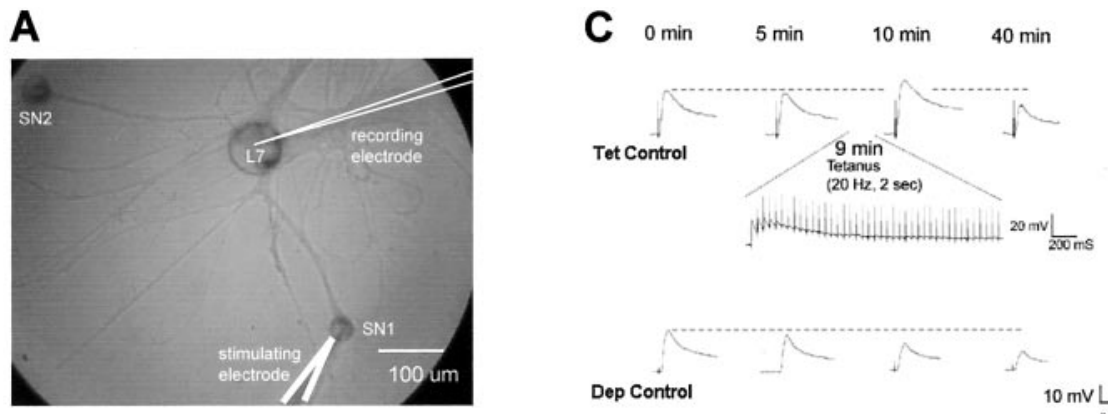

\section{B General protocol}

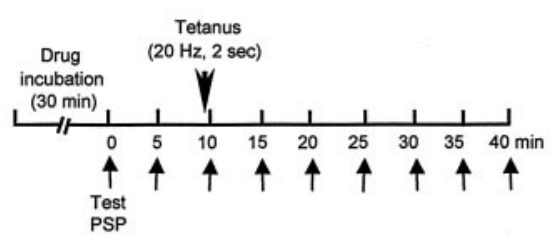

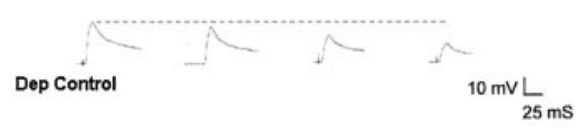

D

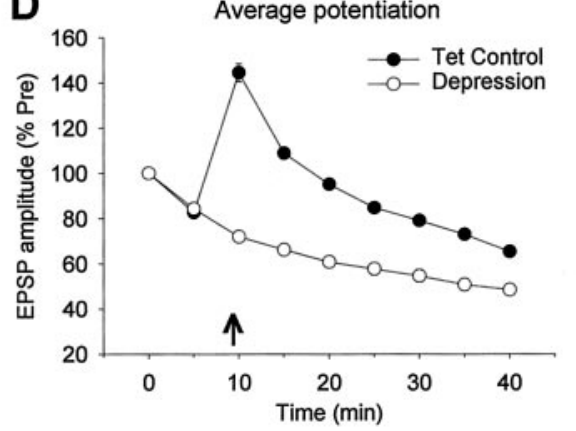

Figure 1. The experimental preparation and protocol. A, Micrograph of an Aplysia gill motor neuron (L7) isolated from the abdominal ganglion of a juvenile animal and cocultured with two sensory neurons (SN) from the pleural ganglion of an adult animal. One of the sensory neurons was stimulated with an extracellular electrode pressed against the cell body, and the evoked EPSP was recorded with a sharp intracellular electrode in the motor neuron. $B$, General protocol. After 30 min of rest or drug incubation, the EPSP was tested once every $5 \mathrm{~min}$ for $40 \mathrm{~min}$. Tetanic stimulation $(20 \mathrm{~Hz}, 2 \mathrm{sec})$ was delivered to the sensory neuron 1 min before the third test. C, Examples of the PSPs in a representative potentiation experiment and in a control experiment without tetanic stimulation. $D$, The average change in the PSP in all of the no-drug potentiation experiments $(n=119)$ and test-alone (homosynaptic depression) control experiments $(n=37)$ in this study. The data have been normalized to the value on the pretest in each experiment. The arrow indicates the time of tetanic stimulation, and the error bars indicate the SEM. There was no difference between experiments with and without DMSO, which have been pooled.

in various ways to produce novel as well as known types of plasticity.

\section{Materials and Methods}

Cell culture preparation. Aplysia cocultures (an L7 gill motor neuron and two pleural sensory neurons) were prepared as described previously (Schacher, 1985; Bao et al., 1997) (Fig. 1A). L7 motor neurons were isolated from juvenile (1-3 gm) animals, and pleural sensory neurons were isolated from adults $(70-120 \mathrm{gm})$. All animals were purchased from the Howard Hughes Medical Institute Mariculture Facility (Miami, FL). The cell culture medium consisted of 50\% filtered hemolymph and 50\% L-15 medium (Flow Laboratories, McLean, VA) supplemented with salts, D-glucose, glutamine, penicillin, and streptomycin (Bao et al., 1997).

Electrophysiology. Four to six days after plating of the cells, a motor neuron was impaled with a microelectrode $(10-20 \mathrm{M} \Omega)$ filled with $2.5 \mathrm{M}$ $\mathrm{KCl}$. Because it is not possible to produce homosynaptic potentiation while the sensory neuron is impaled with an intracellular electrode (Eliot et al., 1994b), extracellular stimulation was used to stimulate one of the sensory neurons and produce an EPSP. The other sensory neuron was not used in these experiments, although its presence is more physiological and may affect the results (Schacher et al., 1997). The motor neuron was hyperpolarized $30 \mathrm{mV}$ below resting potential during the recording periods to allow measurement of the EPSP without action potentials. After 30 min of rest or drug incubation, the EPSP was tested once every 5 min for $40 \mathrm{~min}$. A tetanus $(20 \mathrm{~Hz}$ for $2 \mathrm{sec})$ was applied to the sensory neuron $1 \mathrm{~min}$ before the third EPSP (Fig. $1 \mathrm{~B}$ ). During the tetanus, the stimulation intensity was increased $20-30 \%$ above that used to evoke the previous PSP, which was sufficient to produce one-for-one EPSPs. In some experiments (test-alone or homosynaptic depression control), the tetanus was omitted. All experiments were performed at room tempera-

ture $\left(20-23^{\circ} \mathrm{C}\right)$, and the culture dish was continuously perfused at a rate of $0.5 \mathrm{ml} / \mathrm{min}$ with $50 \%$ supplemented L- 15 medium and $50 \%$ artificial seawater.

Drugs were included in the perfusion solution from the beginning of the 30 min rest period until the end of the experiment. The following drugs were used: APV and $\mathrm{N}^{\omega}$-nitro-Larginine (Sigma, St. Louis, MO); nitrendipine, thapsigargin, 2-aminoethoxydiphenylborate (2APB), ryanodine, K252a, staurosporine, H7, KT5720, KT5823, lavendustin A, U0126, KN93, and calmidazolium (Calbiochem, La Jolla, CA); LY367385 and DNQX (Tocris Cookson, Ballwin, MO); oxymyoglobin and metmyoglobin (prepared as described in Lev-Ram et al., 1995). The concentrations of these drugs were generally 10 times the $\mathrm{IC}_{50}$ reported by the manufacturer. Because that is based on mammalian data, we were also guided by previously published Aplysia studies when possible. Nitrendiprine, thapsigargin, $2 \mathrm{APB}$, ryanodine, staurosporine, KT5720, KT5823, lavendustin A, U0126, KN93, and calmidazolium were prepared as stock solutions in DMSO and diluted to a final concentration of $0.1 \%$ DMSO. In those experiments, the control saline contained $0.1 \%$ DMSO.

Intracellular injections. Substances were injected by pressure from a 3-6 $\mathrm{M} \Omega$ electrode connected to a Pico-injector (Medical Systems, Greenvale, NY). The injection solution consisted of $0.5 \mathrm{M}$ potassium acetate, $10 \mathrm{~mm}$ Tris$\mathrm{HCl}$ to adjust the $\mathrm{pH}$ to $7.5,0.2 \%$ fast green to visualize the injection, and one of the following: 8-amino-cyclic ADP ribose (8NcADPR; Sigma; or Molecular Probes, Eugene, OR); heparin and CamKII 281-309 (Calbiochem); the light chain of botulinum toxin B (List Biological Labs, Campbell, CA). The concentrations of these agents in the electrode were generally 100 times the reported $\mathrm{IC}_{50}$. The botulinum toxin solution also contained $5 \mathrm{~mm}$ DTT, $20 \mathrm{~mm}$ sodium phosphate, and $10 \mathrm{~mm} \mathrm{NaC1}$. In control experiments, the vehicle solution was injected into the neuron. The injection was terminated when the cell body was visibly green and began to swell. The electrode was then removed and replaced with a stimulating (sensory neuron) or recording (motor neuron) electrode, and the preparation was rested $30 \mathrm{~min}$ before the experiment began.

Data analysis. Drug experiments were compared with interleaved control experiments. The data were normalized to the first EPSP and are presented as mean \pm SEM. The normalized data were analyzed with twoor three-way ANOVA with one repeated measure (time), followed by planned comparisons of the individual groups if there were more than two. $p<0.05$ is considered significant.

\section{Results}

\section{Homosynaptic potentiation is long-lasting}

Because the sensory-motor neuron PSPs undergo homosynaptic depression as well as potentiation, the potentiation must be assessed in comparison with a test-alone (depression) control group. In agreement with previous studies (Eliot et al., 1994a,b; Bao et al., 1997), testing the PSP even once every 5 min produced substantial depression ( $84 \pm 2 \%$ of the first PSP on the second test and $48 \pm 2 \%$ on the ninth test, 40 min after the first PSP) (Fig. $1 C, D)$. Tetanic stimulation of the sensory neuron $(20 \mathrm{~Hz}, 2 \mathrm{sec}) 9$ min after the first PSP produced homosynaptic potentiation that was significant compared with the depression control overall $\left(F_{(1,154)}=108.40 ; p<0.0001\right)$ and at every time point for $30 \mathrm{~min}$ after the tetanus $(p<0.01$ in each case). Compared with the 
depression control, the PSP was approximately doubled 1 min after the tetanus, and the potentiation then decayed with a time constant of $\sim 30 \mathrm{~min}$. Neither the potentiation nor the depression from 10 to 40 min correlated significantly with the amplitude of the PSP on the pretest $(r=$ -0.123 and -0.081 , respectively). However, the depression at 5 min did correlate with the pretest, with less depression when the pretest was larger $(r=-0.266 ; p<$ 0.001 ). These results suggest that the early and later phases of depression may involve somewhat different mechanisms.

\section{Homosynaptic potentiation does not} require $\mathrm{Ca}^{2+}$ influx through NMDA receptor channels or voltage-gated $\mathrm{Ca}^{2+}$ channels

Because the potentiation lasts $>30 \mathrm{~min}$ (Fig. $1 D$ ) and is reduced by postsynaptic BAPTA or hyperpolarization (Bao et al., 1997), it has similarities to LTP in mammals (Bliss and Collingridge, 1993) and Aplysia (Lin and Glanzman, 1994a,b). We, therefore, tested whether the potentiation involves similar sources of calcium.

We first examined the role of $\mathrm{Ca}^{2+}$ influx through NMDA-type glutamate receptor channels, which is usually required for LTP in the CA1 region of hippocampus (Bliss and Collingridge, 1993). The PSPs at the sensory-motor neuron synapses are thought to be glutamatergic and to have NMDA-like properties (Dale and Kandel, 1993), and a competitive antagonist of NMDA receptors, APV $(50 \mu \mathrm{M})$, blocks LTP at these synapses (Lin and Glanzman, 1994b). However, APV at the same concentration had no significant effect on homosynaptic potentiation (Fig. $2 A$ ).

LTP produced with stronger induction protocols has a nonNMDA component both in CA1 hippocampus (Bliss and Collingridge, 1993) and in Aplysia (Lin and Glanzman, 1994b). In hippocampus, this component involves L-type voltagedependent calcium channels. However, nitrendipine $(10 \mu \mathrm{M})$, which blocks $\sim 90 \%$ of the L-type current in Aplysia (Eliot et al., 1993), also had no significant effect on homosynaptic potentiation (Fig. $2 B$ ).

To test whether $\mathrm{Ca}^{2+}$ influx through some other type of channel might be important, we examined homosynaptic potentiation with extracellular $\mathrm{Ca}^{2+}$ reduced from 10 to $2 \mathrm{mM}$. Decreasing extracellular $\mathrm{Ca}^{2+}$ decreased the amplitude of the initial PSP, as expected (Table 1), and also decreased short-term depression during the tetanus (fifth/first PSP $=39.3$ vs $13.1 \%$ in normal $\left.\mathrm{Ca}^{2+} ; t_{(16)}=2.68 ; p<0.05\right)$, perhaps because of an increase in opposing frequency facilitation (Creager et al., 1980). However, reducing extracellular $\mathrm{Ca}^{2+}$ had no significant effect on homosynaptic potentiation (Fig. 2C). Thus, unlike PTP at frog neuromuscular junction (Rosenthal, 1969) and either PTP or LTP in CA1 hippocampus (Dunwiddie and Lynch, 1979; Anwyl et al., 1988; Mulkeen et al., 1988), homosynaptic potentiation at the Aplysia sensory-motor neuron synapses does not depend importantly on the magnitude of $\mathrm{Ca}^{2+}$ influx during the tetanus.

Another possible source of $\mathrm{Ca}^{2+}$ is through stimulation of metabotropic glutamate receptors, which also play an important
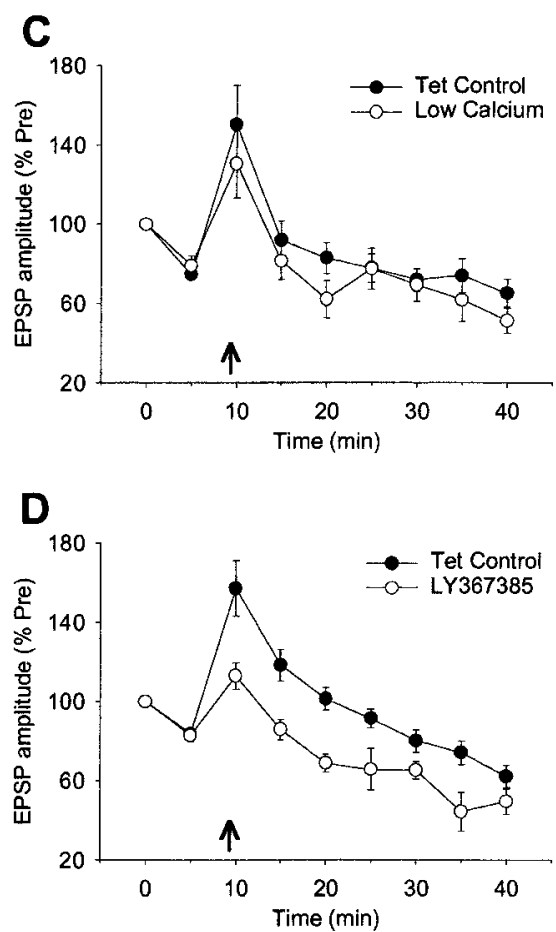

Figure 2. Homosynaptic potentiation does not require $\mathrm{Ca}^{2+}$ influx through NMDA receptor channels or voltage-dependent intic potentiation is not affected by an inhibitor of L-type $\mathrm{Ca}^{2+}$ channels, nitrendipine $(10 \mu \mathrm{M})$. C, Homosynaptic potentiation is also not affected by reducing extracellular $\mathrm{Ca}^{2+}$ from 10 to $2 \mathrm{~mm}$. D, Homosynaptic potentiation is reduced by an antagonist of type I metabotropic glutamate receptors, LY367385 (300 $\mu \mathrm{m})$.

role in LTP in hippocampus (Bashir et al., 1993). An inhibitor of type I metabotropic receptors, LY367385 (300 $\mu \mathrm{M})$ significantly reduced homosynaptic potentiation $\left(F_{(1,13)}=7.95 ; p<0.02\right)$ (Fig. $2 D$ ), suggesting that metabotropic receptors may play an important role in this potentiation as well.

\section{Homosynaptic potentiation involves $\mathrm{Ca}^{2+}$ release from intracellular stores}

In mammals, type I metabotropic glutamate receptors are linked to the release of $\mathrm{Ca}^{2+}$ from intracellular stores. An inhibitor of endoplasmic reticulum ATPase, thapsigargin $(10 \mu \mathrm{M})$, which depletes intracellular $\mathrm{Ca}^{2+}$ stores, greatly reduced homosynaptic potentiation $\left(F_{(1,32)}=34.95 ; p<0.001\right)$ (Fig. $\left.3 A, B\right)$, suggesting that $\mathrm{Ca}^{2+}$ release from intracellular stores plays an important role in the potentiation. There was no significant interaction between the effect of thapsigargin and time, suggesting that intracellular $\mathrm{Ca}^{2+}$ release is important for both the early and late phases of potentiation.

There was also a trend for thapsigargin to increase homosynaptic depression on the test before the tetanus, $5 \mathrm{~min}$ after the first PSP (Table 1). However, when we ran two additional groups (test-alone or depression controls) without tetanic stimulation, we found that thapsigargin had no significant effect on the depression from 10 to $40 \mathrm{~min}$. These results indicate that the effect of thapsigargin on potentiation is not because of enhanced depression. In the presence of thapsigargin, the potentiation group actually went significantly below the depression control group by $40 \mathrm{~min}$, in part because the PSP gradually fell to zero in six of 11 experiments in the potentiation group but none in the depression group (the PSP fell to zero in only one of the 156 no drug experiments in Fig. 1D). The disappearance of the PSP is not likely to be because of a failure of presynaptic stimulation, because it oc- 
Table 1. Effects of drugs that did or did not reduce homosynaptic potentiation on some additional measures of plasticity

\begin{tabular}{|c|c|c|c|c|c|c|c|c|}
\hline & \multicolumn{2}{|l|}{$N$} & \multicolumn{2}{|c|}{ Pretest (mV) } & \multicolumn{2}{|c|}{$5^{\prime} /$ Pre (\%) } & \multicolumn{2}{|c|}{ Tet. Area/first (msec) } \\
\hline & Drug & Control & Drug & Control & Drug & Control & Drug & Control \\
\hline \multicolumn{9}{|c|}{ Reduced potentiation } \\
\hline LY & 5 & 10 & 10.7 & 12.2 & 82.7 & 83.7 & 2673 & 2804 \\
\hline Thap & $11+8$ & $8+9$ & 15.3 & 14.9 & 79.0 & 84.4 & $543^{* *}$ & 2682 \\
\hline $2 A P B$ & 7 & 9 & 11.1 & 20.7 & 75.6 & 82.5 & 2866 & 2561 \\
\hline Ryan & 8 & 6 & 9.5 & 6.9 & 78.7 & 83.8 & $1300^{*}$ & 2705 \\
\hline Hep MN & 10 & 12 & 11.2 & 9.3 & $68.2^{* *}$ & 85.8 & 1632 & 2214 \\
\hline 8N SN & 10 & 11 & 10.4 & 15.6 & $76.7^{+}$ & 88.3 & $1052^{+}$ & 1937 \\
\hline $\mathrm{K} 252 \mathrm{a}$ & $6+7$ & $4+8$ & 8.7 & 8.6 & $70.3^{* *}$ & 84.1 & 3053 & 1173 \\
\hline Staur & 6 & 9 & 12.8 & 11.2 & 70.9 & 80.1 & 1693 & 1477 \\
\hline U0126 & 9 & 8 & 10.5 & 11.3 & 73.5 & 82.3 & 2035 & 2062 \\
\hline KN93 & $7+9$ & $5+6$ & 18.5 & 16.5 & $74.8^{+}$ & 83.7 & 1608 & 1981 \\
\hline Calmid & 6 & 7 & 18.3 & 18.1 & 80.8 & 89.1 & 1946 & 2190 \\
\hline Pep MN & 10 & 11 & 9.4 & 13.8 & 79.5 & 82.2 & 1142 & 1172 \\
\hline Pep SN & 10 & 11 & 9.4 & 14.3 & 72.6 & 78.4 & 1444 & 1646 \\
\hline DNQX & $7+6$ & $9+4$ & $5.9^{* *}$ & 17.3 & $75.6^{*}$ & 85.9 & 1963 & 2285 \\
\hline BoTx MN & 11 & 9 & $19.9^{* *}$ & 8.9 & $77.5^{+}$ & 85.6 & $994^{*}$ & 2265 \\
\hline \multicolumn{9}{|c|}{ Did not reduce potentiation } \\
\hline APV & 20 & 23 & 11.0 & 11.4 & 84.3 & 81.0 & & \\
\hline Nit & 9 & 7 & 19.0 & 12.9 & 84.6 & 84.4 & & \\
\hline Low $\mathrm{Ca}^{2+}$ & 10 & 8 & $6.0^{* *}$ & 22.8 & 79.0 & 74.5 & & \\
\hline 8N MN & 12 & 12 & 14.5 & 9.3 & 82.4 & 85.8 & & \\
\hline Hep SN & 7 & 11 & 11.9 & 15.6 & 87.9 & 88.3 & & \\
\hline $\mathrm{H} 7$ & 5 & 5 & 18.1 & 14.3 & 86.3 & 78.8 & & \\
\hline KT5720 & 9 & 9 & 10.4 & 7.6 & 78.3 & 83.7 & & \\
\hline KT5823 & 4 & 4 & 9.1 & 7.0 & 85.7 & 89.2 & & \\
\hline LavA & 6 & 4 & 21.3 & 16.2 & 80.0 & 82.6 & & \\
\hline NOArg & 4 & 7 & 9.0 & 15.6 & 79.8 & 81.6 & & \\
\hline $0 x y$ & 9 & 9 & 15.2 & 12.9 & 90.1 & 89.8 & & \\
\hline
\end{tabular}

The $N$ and mean amplitude of the PSP on the pretest (in $\mathrm{mV}$ ) and the second test, 5 min later (normalized to the pretest) for each drug group and its matching control group. For drugs that were tested on homosynaptic depression as well as potentiation, both $N$ s are given and the data have been pooled. For drugs that significantly reduced potentiation, we also measured the total depolarization during the tetanus, normalized to the first PSP in the tetanus, as an index of short-term plasticity. ${ }^{* *} p<0.01 ;{ }^{*} p<0.05 ;{ }^{+} p<0.05$; one-tail compared with control.

curred gradually, rather than abruptly. Moreover, thapsigargin still significantly reduced homosynaptic potentiation, even when the experiments with zero responses were excluded $(p<0.01)$.

Thapsigargin also significantly reduced the total postsynaptic depolarization during the tetanus (area $=6,614 \mathrm{vs} 40,661 \mathrm{mV} \times$ msec in the control group; $t_{(16)}=5.35 ; p<0.001$ ). This effect was due in part to increased homosynaptic depression before the first PSP of the tetanus (first/Pre $=71.3$ vs $79.5 \%$ ), similar to the increased depression on the $5 \mathrm{~min}$ test, and in part to increased short-term depression during the tetanus $\left(t_{(16)}=6.26 ; p<0.001\right)$ (Table 1, Fig. $4 C$ ). These results suggest that thapsigargin might act by reducing postsynaptic depolarization during the tetanus and, thus, blocking other voltage-dependent mechanisms of potentiation. However, two such mechanisms, $\mathrm{Ca}^{2+}$ influx though NMDA receptor channels or voltage-dependent $\mathrm{Ca}^{2+}$ channels, do not play important roles in homosynaptic potentiation (Fig. $2 A, B)$. Furthermore, low $\mathrm{Ca}^{2+}$ also reduced postsynaptic depolarization during the tetanus (area $=10,079$ vs $24,419 \mathrm{mV} \times$ msec in the control group; $\left.t_{(16)}=3.71 ; p<0.01\right)$ but did not significantly effect potentiation (Fig. $2 C$ ). In addition, in the control experiments shown in Figure $1 D$, there was no significant correlation between the average percentage of potentiation and the total postsynaptic depolarization during the tetanus $(r=$ 0.103 ). Thus, the reduction in postsynaptic depolarization cannot explain the effect of thapsigargin on potentiation.

Homosynaptic potentiation involves postsynaptic $\mathrm{IP}_{3}$ receptors and presynaptic ryanodine receptors

Thapsigargin depletes both $\mathrm{IP}_{3}$-sensitive and ryanodine-sensitive $\mathrm{Ca}^{2+}$ stores. Type I metabotropic receptors are linked to the production of $\mathrm{IP}_{3}$, and ryanodine receptors play an important role in $\mathrm{Ca}^{2+}$-induced $\mathrm{Ca}^{2+}$ release, suggesting that both stores might be involved. Consistent with that idea, a cell-permeable inhibitor of $\mathrm{IP}_{3}$ receptors, $2 \mathrm{APB}(10 \mu \mathrm{M})$ greatly reduced homosynaptic potentiation $\left(F_{(1,14)}=6.69 ; p<0.05\right)$ (Fig. 3C). Similarly, prolonged (40 $\mathrm{min}$ ) application of a relatively high concentration $(100 \mu \mathrm{M})$ of ryanodine, which binds to a low-affinity site and blocks ryanodine receptors (Meissner, 1986; McPherson et al., 1991) also reduced the potentiation $\left(F_{(1,12)}=33.06 ; p<\right.$ 0.001) (Fig. 3D). Brief (4 min) application of a relatively low concentration $(1 \mu \mathrm{M})$ of ryanodine, which binds to a high-affinity site and activates ryanodine receptors, produced potentiation of the PSP $\left(F_{(1,13)}=7.62 ; p<0.05\right.$ compared with the no drug control) (Fig. 3D, inset), further supporting a role of ryanodine receptors. Like thapsigargin, a high concentration of ryanodine also increased the short-term depression during the tetanus $\left(t_{(12)}=2.91 ; p<0.05\right)$, but $2 \mathrm{APB}$ did not (Table 1, Fig. $4 C$ ). These results suggest that whereas ryanodine-sensitive $\mathrm{Ca}^{2+}$ stores are selectively involved in short-term plasticity during the tetanus, both $\mathrm{IP}_{3}$-sensitive and ryanodine-sensitive $\mathrm{Ca}^{2+}$ stores contribute to homosynaptic potentiation.

Because the potentiation involves $\mathrm{Ca}^{2+}$ in both the presynaptic and postsynaptic neurons (Bao et al., 1997), $\mathrm{Ca}^{2+}$ release from intracellular stores in either neuron might play a role. To test those possibilities, we injected cell impermeable antagonists of either $\mathrm{IP}_{3}$ receptors (heparin) or ryanodine receptors (8NcADPR) into either the sensory neuron or the motor neuron. Injecting heparin $(2 \mathrm{mg} / \mathrm{ml}$ in the electrode) into the motor neuron reduced the potentiation $\left(F_{(1,31)}=5.08 ; p<0.05\right)$ (Fig. $\left.4 A\right)$. However, the reduction in potentiation was more modest than that produced by $2 \mathrm{APB}$ (Fig. $3 \mathrm{C}$ ), perhaps because substances injected into the cell body reach the synapses at a much lower 
concentration. As in the thapsigargin experiments, the PSP gradually fell to zero in two of 10 experiments in the heparin group, but heparin still significantly reduced potentiation when those experiments were excluded ( $p<0.05$; one-tail). In contrast, injecting $8 \mathrm{NcADPR}(20 \mu \mathrm{M})$ into the motor neuron had no significant effect. These results, therefore, suggest that $\mathrm{Ca}^{2+}$ release from postsynaptic $\mathrm{IP}_{3}-$ sensitive stores contributes to homosynaptic potentiation.

By contrast, injecting heparin into the sensory neuron did not have a significant effect on homosynaptic potentiation (Fig. $4 B$ ). However, injecting 8 NcADPR into the sensory neuron did reduce the potentiation $\left(F_{(1,25)}=5.48 ; p<0.05\right)$. Like thapsigargin and postsynaptic heparin, presynaptic $8 \mathrm{NcADPR}$ caused the PSP to fall to zero gradually in three of 10 experiments. Like thapsigargin and ryanodine, presynaptic 8 NcADPR also tended to increase the short-term depression during the tetanus $\left(t_{(19)}=1.94 ; p<0.05\right.$; onetail) (Table 1), but postsynaptic 8 NcADPR and either presynaptic or postsynaptic heparin did not (Fig. 4D). These results support the idea that presynaptic ryanodine receptors contribute to short-term plasticity during the tetanus (Narita et al., 2000; Emptage et al., 2001) and suggest that $\mathrm{Ca}^{2+}$ release from presynaptic ryanodine-sensitive stores also contributes to longer-lasting potentiation.

\section{Homosynaptic potentiation involves}

\section{protein kinases, probably including MAP kinase}

We next began to investigate possible downstream effectors of $\mathrm{Ca}^{2+}$ during homosynaptic potentiation. We first tested the role of protein kinases, many of which can be activated either directly or indirectly by $\mathrm{Ca}^{2+}$ and contribute to hippocampal LTP (Bliss and Collingridge, 1993). A general inhibitor of protein kinases, K252a (200 $\mu \mathrm{M})$ greatly reduced homosynaptic potentiation $\left(F_{(1,21)}=38.12\right.$; $p<0.001$ ) (Fig. 5A). There was also a significant interaction between the effect of K252a and time, but this was eliminated by a log transformation of the data, indicating that the ratio of the control and drug groups was approximately constant over time. Like thapsigargin, K252a also increased homosynaptic depression on the second test, 5 min after the first PSP $\left(F_{(1,23)}=9.93 ; p<0.01\right)$ (Table 1), but it had no significant effect on the depression from 10 to $40 \mathrm{~min}$ in test-alone control experiments. Another general inhibitor of protein kinases, staurosporine $(50 \mu \mathrm{M})$, also reduced potentiation $\left(F_{(1,13)}=\right.$ $15.78 ; p<0.01$ ) (Fig. $5 B$ ). These results suggest that protein phosphorylation plays an important role in the potentiation.

However, a third general inhibitor of protein kinases, H7 (100 $\mu \mathrm{M}$ ), had no significant effect on the potentiation (Fig. $5 C$ ), although a similar concentration of H7 blocks other types of plasticity in these neurons (Braha et al., 1993). H7 is a relatively potent inhibitor of myosin light chain kinase, cAMP-dependent protein kinase (PKA), cGMP-dependent protein kinase (PKG), and PKC in mammals, suggesting that none of these kinases may play a critical role. However, because H7 is thought to be some- what more selective for PKC in Aplysia (Braha et al., 1993), we also tested more specific inhibitors of PKA (KT5720; $2 \mu \mathrm{M} ; n=9$ drug and 9 control) and PKG (KT5823; $1 \mu \mathrm{M} ; n=4$ drug and 4 control). Neither inhibitor had a significant effect on the potentiation, although at similar concentrations they both block classical conditioning in Aplysia (Antonov et al., 2003) (I. Antonov, unpublished data).

We also performed preliminary tests of the possible roles of some other protein kinases that contribute to LTP in hippocampus (O'Dell et al., 1991; English and Sweatt, 1996). An inhibitor of tyrosine kinase, lavendustin A ( $1 \mu \mathrm{M} ; n=6$ and 4$)$ had no significant effect on homosynaptic potentiation, although a higher concentration may be necessary in Aplysia (Purcell and Carew, 2001). However, an inhibitor of MAP kinase, U0126 (10 $\mu \mathrm{M})$, which blocks vesicle mobilization in these neurons at a similar concentration (Angers et al., 2002; Chin et al., 2002), reduced the potentiation $\left(F_{(1,15)}=\right.$ 17.04; $p<0.001$ ) (Fig. $5 D$ ). These results suggest that MAP kinase may contribute to homosynaptic potentiation as well.

\section{Homosynaptic potentiation involves both presynaptic and postsynaptic CamKII}

H7 is known to differ from K252a and staurosporine in being a relatively poor inhibitor of calcium/calmodulin-dependent protein kinase (CamKII), suggesting that CamKII might play an important role. Consistent with that idea, a more specific inhibitor of CamKII, KN93 (5 $\mu \mathrm{M})$, greatly reduced homosynaptic poten- 

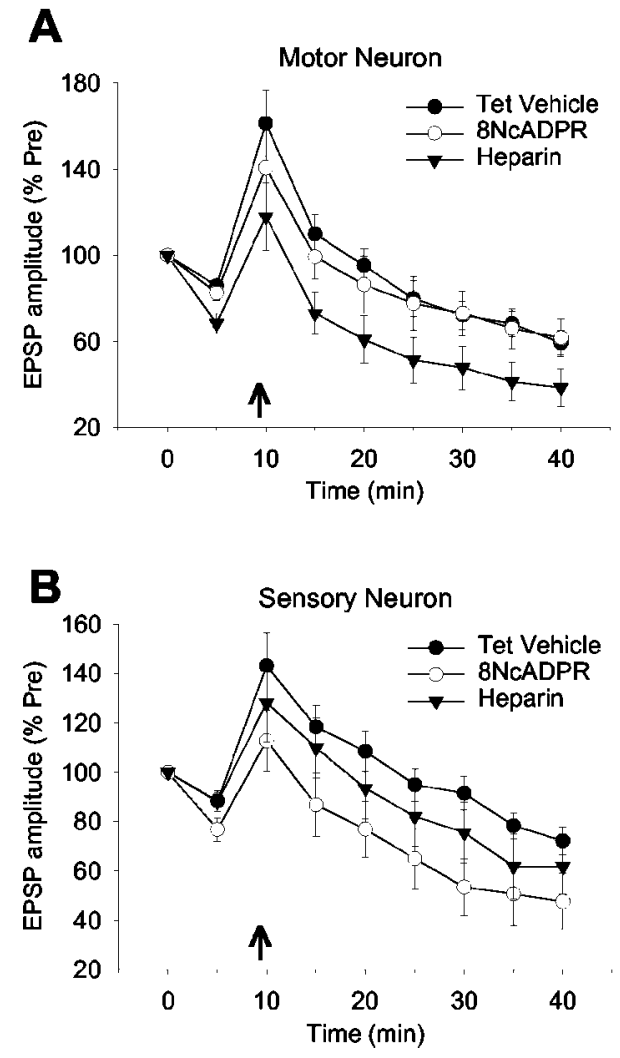
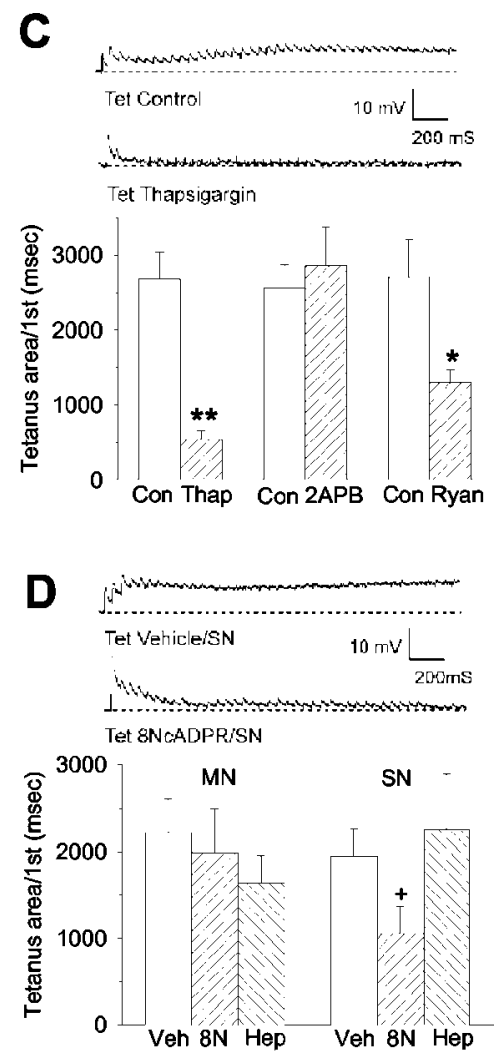

Figure 4. Homosynaptic potentiation involves both presynaptic and postsynaptic $\mathrm{Ca}^{2+}$ release, and short-term plasticity also involves presynaptic $\mathrm{Ca}^{2+}$ release. $A$, Homosynaptic potentiation is significantly reduced by injection of a cell impermeable antagonist of $I_{3}$ receptors (heparin, $2 \mathrm{mg} / \mathrm{ml}$ in the electrode) but not a cell impermeable antagonist of ryanodine receptors (8NcADPR, $20 \mu \mathrm{m}$ in the electrode) into the motor neuron. $B$, Homosynaptic potentiation is significantly reduced by injection of 8 NcADPR, but not heparin, into the sensory neuron. C, Short-term depression during the tetanus is increased by thapsigargin or a high concentration of ryanodine, but not by 2 APB. The data are from the same experiments as Figure 3 . To get an overall index of plasticity during the 2 sec tetanus, we measured the total area under the tetanus (in millivolts $\times$ milliseconds) normalized to the amplitude of the first PSP in the tetanus (in millivolts) in each experiment. D, Short-term depression during the tetanus is increased by presynaptic 8NcADPR but not by postsynaptic 8NcADPR or either presynaptic or postsynaptic heparin. The data are from the same experiments as $A$ and $B$.

tiation $\left(F_{(1,23)}=23.10 ; p<0.001\right)$ (Fig. $\left.6 A\right)$. There was also a significant interaction between the effect of KN93 and time, but this was eliminated by a log transformation of the data, suggesting that CamKII contributes to both early and late potentiation. Like thapsigargin and K252a, KN93 also tended to increase homosynaptic depression on the second test, $5 \mathrm{~min}$ after the first PSP (Table 1), but it had no significant effect on the depression from 10 to $40 \mathrm{~min}$ in test-alone control experiments. An inhibitor of calmodulin, calmidazolium $(10 \mu \mathrm{M})$, which also inhibits Cam kinase in Aplysia (DeReimer et al., 1984), reduced the potentation as well $\left(F_{(1,11)}=5.02 ; p<0.05\right)$ (Fig. 6B). These results suggest the involvement of CamKII in homosynaptic potentiation.

To test whether CamKII acts in either the presynaptic or postsynaptic neuron, we injected a peptide inhibitor, CamKII 281-309, into either the sensory neuron or the motor neuron. Injecting CamKII 281-309 (300 $\mu \mathrm{M}$ in the electrode) into the motor neuron reduced homosynaptic potentiation $\left(F_{(1,19)}=\right.$ 4.62; $p<0.05$ ) (Fig. 6C). Injecting CamKII 281-309 into the sensory neuron also reduced the potentiation $\left(F_{(1,19)}=5.28\right.$; $p<$ 0.05 ) (Fig. $6 D$ ), suggesting that both presynaptic and postsynaptic CamKII contribute to homosynaptic potentiation.
Homosynaptic potentiation does not require nitric oxide, but may involve AMPA receptor insertion

Injecting $\mathrm{Ca}^{2+}$ chelators (Bao et al., 1997), inhibitors of intracellular $\mathrm{Ca}^{2+}$ release (Fig. 4), or inhibitors of CamKII (Fig. 6) into either the sensory neuron or the motor neuron produces a substantial reduction in potentiation. These observations suggest that the potentiation involves both presynaptic and postsynaptic mechanisms, which might interact through transsynaptic signaling. Because nitric oxide (NO) synthase (NOS) is stimulated by $\mathrm{Ca}^{2+}$ and NO can act as a transsynaptic messenger during hippocampal LTP (Hawkins et al., 1998), we tested its possible involvement in homosynaptic potentiation. An inhibitor of NOS, $\mathrm{N}^{\omega}$-nitro-Larginine $(500 \mu \mathrm{M})$ had no significant effect on the potentiation (Fig. $7 A$ ), although at the same concentration it blocks classical conditioning in Aplysia (Antonov et al., 2001). Similarly, a scavenger of extracellular NO, oxymyoglobin $(10 \mu \mathrm{M})$, also had no significant effect compared with the inactive form, metmyoglobin (Fig. 7B). These results suggests that NO does not play an important role in the potentiation. Because oxymyoglobin also scavenges carbon monoxide (CO), another possible transsynaptic messenger, these results suggest that $\mathrm{CO}$ is not involved either.

Both CamKII and MAP kinase contribute to LTP in hippocampus through insertion of AMPA-type glutamate receptors into the postsynaptic membrane (Malinow and Malenka, 2002). Aplysia sensorymotor neuron PSPs are thought to have both AMPA and NMDA components (Glanzman, 1994; Conrad et al., 1999; Antonov et al., 2003), and insertion of AMPA-type receptors may also contribute to facilitation by serotonin in Aplysia (Chitwood et al., 2001). To begin to test whether that mechanism contributes to homosynaptic potentiation as well, we examined potentiation in the presence of a low concentration $(5 \mu \mathrm{M})$ of the AMPA receptor antagonist DNQX, which should decrease the importance of any selective changes in the AMPA component. DNQX greatly reduced homosynaptic potentiation $\left(F_{(1,22)}=17.70 ; p<0.001\right)$ (Fig. 7C). Like thapsigargin, K252a, and KN93, DNQX also increased homosynaptic depression on the second test, 5 min after the first PSP $\left(F_{(1,24)}=5.16 ; p<0.05\right)$ (Table 1$)$, but it had no significant effect on the depression from 10 to $40 \mathrm{~min}$ in test alone control experiments. In the presence of DNQX, the potentiation group went significantly below the depression control group by $40 \mathrm{~min}$, in part because the PSP gradually fell to zero in two of seven experiments in the potentiation group but none in the depression group. However, the potentiation group still went significantly below the depression control group even when the experiments with zero responses were excluded. As expected, DNQX also reduced the amplitude of the initial PSP (Table 1) and the postsynaptic depolarization during the tetanus (area $=7,119$ vs 28,755 $\mathrm{mV} \times \mathrm{msec}$ in the control group). However, these effects prob- 
ably do not explain the reduction in homosynaptic potentiation, because low $\mathrm{Ca}^{2+}$ had similar effects without affecting the potentiation (Fig. $2 \mathrm{C}$ ). The low $\mathrm{Ca}^{2+}$ result also argues against an important role of $\mathrm{Ca}^{2+}$ influx through $\mathrm{Ca}^{2+}$ permeable AMPA receptors, although that possibility is not ruled out.

As another way to test the role of AMPA receptor insertion, we injected the motor neuron with the light chain of botulinum toxin type B, which blocks delivery of new receptors to the postsynaptic membrane though exocytosis. Botulinum toxin $(0.5 \mu \mathrm{M}$ in the electrode) reduced homosynaptic potentiation $\left(F_{(1,18)}=12.43 ; p<\right.$ 0.01 ) (Fig. $7 D)$, consistent with a role of postsynaptic exocytosis in the potentiation. However, postsynaptic botulinum toxin also had some other unusual effects. First, there was a significant interaction between the effect of botulinum toxin and time that was not eliminated by a log transformation of the data, suggesting that, unlike any of the other agents that we tested, botulinum toxin selectively affected the early phase of potentiation. Second, postsynaptic botulinum toxin also increased the amplitude of the initial PSP $\left(t_{(18)}=2.91 ; p<0.01\right)$ (Table 1) and increased short-term depression during the tetanus $\left(t_{(17)}=2.71 ; p<0.05\right)$ (Table 1$)$. Although botulinum toxin still significantly reduced homosynaptic potentiation when these effects were factored out in ANCOVA, they suggest that the toxin may not act simply by blocking AMPA receptor insertion. The effects on the amplitude and short-term depression of the PSP are the reverse of those with low $\mathrm{Ca}^{2+}$ (Fig. $2 \mathrm{C}$ ), suggesting that postsynaptic botulinum toxin may increase the presynaptic probability of release (perhaps by blocking release of an inhibitory retrograde signal). Thus, although our results tend to support the possible involvement of AMPA receptor insertion in homosynaptic potentiation, botulinum toxin may also affect other mechanisms.

\section{Discussion}

\section{Mechanisms of homosynaptic potentiation}

Bao et al. (1997) previously found that homosynaptic potentiation at Aplysia sensory-motor neuron synapses in isolated cell culture involves both presynaptic and postsynaptic $\mathrm{Ca}^{2+}$. We have now investigated the sources of $\mathrm{Ca}^{2+}$ and some of its downstream targets. Our results suggest that the potentiation involves intracellular $\mathrm{Ca}^{2+}$ release from both postsynaptic $\mathrm{IP}_{3}$-sensitive and presynaptic ryanodine-sensitive stores (Figs. 3, 4) and also both presynaptic and postsynaptic CamKII and probably MAP kinase (Figs. 5, 6). In addition, the potentiation may involve postsynaptic AMPA receptor insertion (Figs. 7C,D). Intracellular $\mathrm{Ca}^{2+}$ release and CamKII are similarly thought to play some role in the spike broadening-independent component of facilitation by serotonin at Aplysia sensory-motor neuron synapses (Boyle et al., 1984; Nakanishi et al., 1997), and AMPA receptor insertion may also contribute to facilitation by serotonin in the same time range as the potentiation (around $30 \mathrm{~min}$ ) (Chitwood et al., 2001; Li et al., 2001). Like homosynaptic potentiation, AMPA receptor
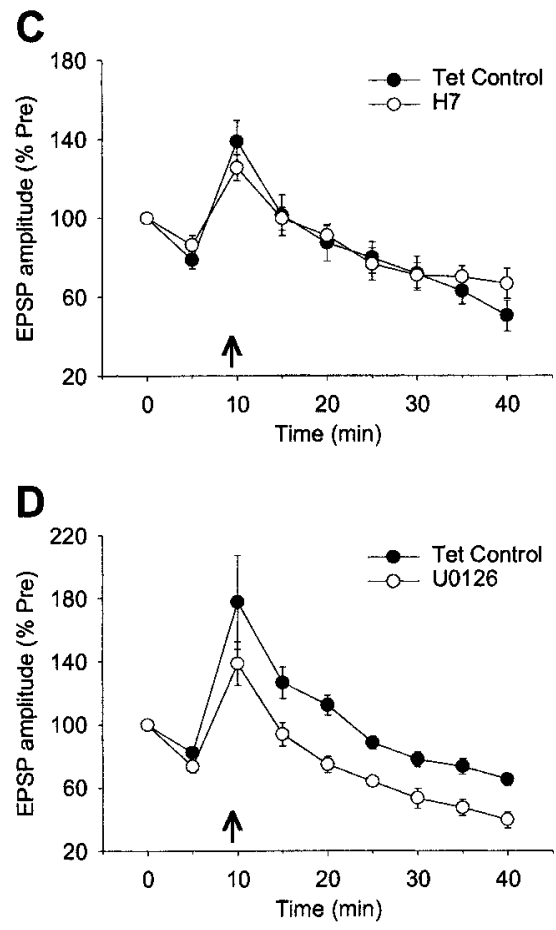

Figure 5. Homosynaptic potentiation involves protein kinases, probably including MAP kinase. $A$, Homosynaptic potentiation M). C, Homosynaptic potentiation is not reduced by a third general inhibitor of protein kinases, H7 (100 $\mu \mathrm{M})$. D, Homosynaptic potentiation is reduced by an inhibitor of MAP kinase, U0126 (10 $\mu \mathrm{M})$.

insertion is thought to involve metabotropic receptors linked to $\mathrm{Ca}^{2+}$ release from postsynaptic $\mathrm{IP}_{3}$-sensitive stores in Aplysia (Chitwood et al., 2001; Li and Glanzman, 2002) and postsynaptic CamKII and MAP kinase in hippocampus (Malinow and Malenka, 2002). However, because the agents that we used to test the possible role of AMPA receptor insertion in homosynaptic potentiation (DNQX and botulinum toxin) may have had additional actions, it will be necessary to test that idea with other methods.

In the presence of a few of the drugs that we used (thapsigargin, postsynaptic heparin, presynaptic $8 \mathrm{NcADPR}$, and DNQX), the PSP gradually fell to zero in some of the experiments in the tetanus group but not in the depression control group. This result suggests that the tetanus caused depletion of some factor that could not be restored in the presence of the drug. Because these drugs had both presynaptic and postsynaptic actions, at least two hypotheses seem possible: (1) the drugs might cause depletion of AMPA receptors by blocking receptor insertion, if the tetanus stimulates both insertion and removal; and (2) they might cause depletion of presynaptic vesicles by blocking vesicle mobilization. Like homosynaptic potentiation, vesicle mobilization is thought to involve $\mathrm{Ca}^{2+}$ release from intracellular stores $(\mathrm{Ku}-$ romi et al., 2002) and phosphorylation by MAP kinase in Aplysia (Angers et al., 2002; Chin et al., 2002) and by CamKII in vertebrates (Greengard et al., 1993).

Our experiments also provide some information about mechanisms of homosynaptic depression. Notably, almost all of the drugs that decreased homosynaptic potentiation also increased homosynaptic depression on the second test, $5 \mathrm{~min}$ after the first PSP (Table 1), but the representative drugs that we tested more 

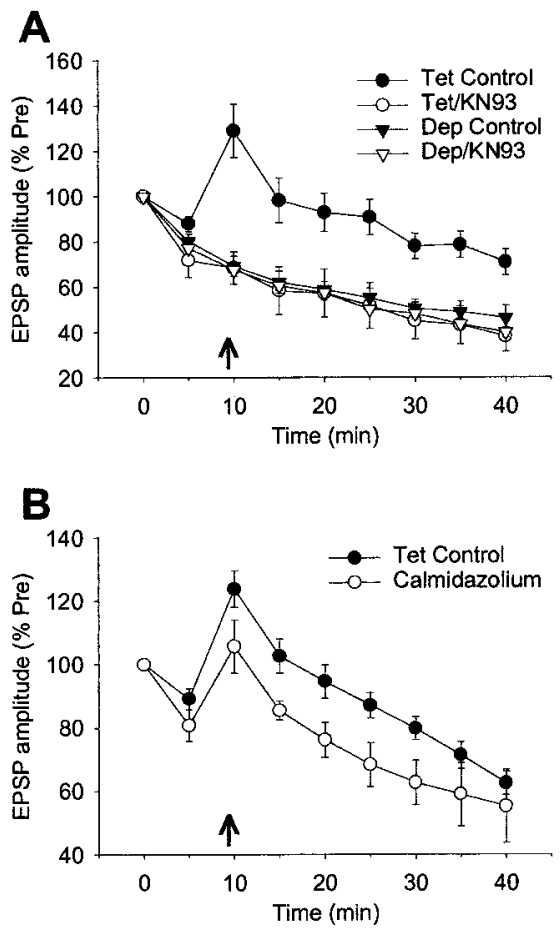
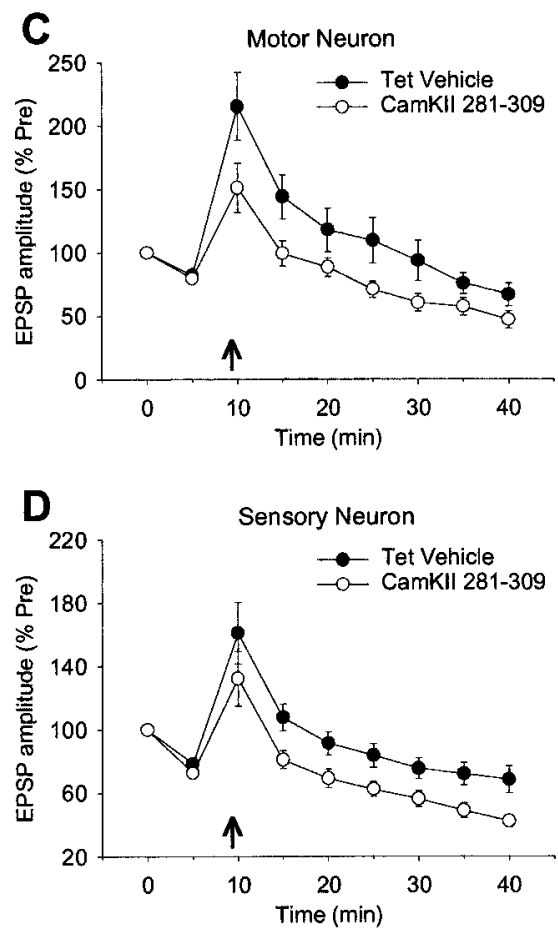

Figure 6. Homosynaptic potentiation involves both presynaptic and postsynaptic CamKII. A, Homosynaptic potentiation is greatly reduced by a more specific inhibitor of CamKII, KN93 (5 $\mu \mathrm{M})$. KN93 also tended to increase homosynaptic depression on the second test, 5 min after the first PSP, but had no significant effect on the depression from 10 to $40 \mathrm{~min}$. There was a significant drug $\times$ tetanus interaction $\left(F_{(1,23)}=10.67 ; p<0.01\right)$ in a three-way ANOVA with one repeated measure (time) for the data from 10 to $40 \mathrm{~min}$. $B$, Homosynaptic potentiation is also reduced by an inhibitor of calmodulin, calmidazolium (10 $\mu$ m). C, Homosynaptic potentiation is reduced by injection of a peptide inhibitor of (amKII, CamKII 281-309 (300 $\mu$ m in the electrode) into the motor neuron. D, Homosynaptic potentiation is also reduced by injection of CamKII 281-309 into the sensory neuron.

fully (a general inhibitor of intracellular $\mathrm{Ca}^{2+}$ release, thapsigargin; a general inhibitor of protein kinases, K252a; a more selective inhibitor of CamKII, KN93; and an AMPA receptor antagonist, DNQX) did not affect the depression from 10 to $40 \mathrm{~min}$, indicating that their effects on potentiation are not because of enhanced depression. Chin et al. (2002) made a similar observation with the MAP kinase inhibitor U0126. In addition, we found that the amplitude of the PSP on the first test had a significant negative correlation with the 5 min depression but not the depression from 10 to $40 \mathrm{~min}$. One possible explanation for these results is that the first test transiently engages the same mechanisms of potentiation as the tetanus, and these counteract the depression at $5 \mathrm{~min}$. An additional implication of these results is that the depression from 10 to 40 min does not involve any of the mechanisms that we tested.

\section{Comparison with other forms of homosynaptic potentiation} We have previously referred to the potentiation produced with this protocol $(20 \mathrm{~Hz}, 2 \mathrm{sec}$ tetanus at Aplysia sensory-motor neuron synapses in isolated cell culture) as PTP because it shares many features with PTP in other systems: it is produced by rather mild tetanic stimulation and is accompanied by an increase in the frequency of spontaneous miniature EPSPs with no change in their amplitude (Eliot et al., 1994b), and it is blocked by presynaptic EGTA (Bao et al., 1997) but not by APV (Kononenko and Hawkins, 1998). These features are all consistent with residual presynaptic $\mathrm{Ca}^{2+}$, which is thought to be the primary mechanism of PTP at most synapses (Zucker and Regehr, 2002). Furthermore, like potentiation at the sensory-motor neuron synapses, PTP in some systems involves $\mathrm{Ca}^{2+}$ release from presynaptic ryanodine sensitive stores (Narita et al., 2000) and may also involve presynaptic CamKII (Greengard et al., 1993; cf. Zucker and Regehr, 2002). In addition, the potentiation was originally thought to last $10-15 \mathrm{~min}$, which is within the range of PTP.

However, more careful analysis of group data (Fig. $1 D$ ) shows that the potentiation lasts $>30 \mathrm{~min}$, which is in the range that is usually referred to as LTP. Moreover, like LTP in the CA1 region of hippocampus (Bliss and Collingridge, 1993) or LTP produced by a stronger stimulation protocol at Aplysia sensory-motor neuron synapses (Lin and Glanzman, 1994a,b), the potentiation is reduced by postsynaptic BAPTA or hyperpolarization (Bao et al., 1997). Potentiation with a similar protocol in the ganglion can also be reduced by postsynaptic BAPTA (Schaffhausen et al., 2001). Like CA1 LTP (Malinow and Malenka, 2002), the potentiation also involves MAP kinase and postsynaptic CamKII (Figs. 5, 6), and it may involve postsynaptic AMPA receptor insertion (Fig. 7). However, unlike LTP in CA1 hippocampus or Aplysia, the potentiation is not blocked by APV (Fig. $2 A$ ), and it is also not blocked by inhibition of L-type voltage-dependent $\mathrm{Ca}^{2+}$ channels (Fig. $2 B)$.

The potentiation, thus, has similarities with either PTP or LTP in CA1 hippocampus, but it seems to differ from both because it is not significantly affected by a fivefold reduction in extracellular $\mathrm{Ca}^{2+}$ (Dunwiddie and Lynch, 1979; Anwyl et al., 1988; Mulkeen et al., 1988) (Fig. 2C), although the normal $\mathrm{Ca}^{2+}$ level is also higher in Aplysia. Furthermore, unlike PTP and LTP in CA1, the early (1 min) and late (30 min) parts of the potentiation are not differentially affected by any of the drugs that we have tested, as indicated by the lack of a significant drug $\times$ time interaction on the log transformed data (with the exception of postsynaptic botulinum toxin) (Fig. 7D). For these reasons, we now refer to the increase in the EPSP with the more neutral term, "homosynaptic potentiation."

Because homosynaptic potentiation involves metabotropic glutamate receptors linked to $\mathrm{Ca}^{2+}$ release from intracellular stores (Figs. 2D, 3, 4A), it may be more similar to LTP onto hippocampal interneurons (Woodhall et al., 1999; Perez et al., 2001). Metabotropic receptors linked to $\mathrm{Ca}^{2+}$ release also contribute to CA1 LTP (Bortolotto and Collingridge, 1993; Wilsch et al., 1998) and may play a role in mossy fiber LTP as well (Yeckel et al., 1999; Kapur et al., 2001). Homosynaptic potentiation also has mechanistic similarities to hippocampal LTD, which is thought to involve intracellular $\mathrm{Ca}^{2+}$ release from both postsynaptic $\mathrm{IP}_{3}$ sensitive stores and presynaptic ryanodine-sensitive stores (Reyes and Stanton, 1996; Reyes-Harde et al., 1999a,b; Unni and Siegelbaum, 2001), leading to activation of presynaptic CamKII (Stanton and Gage, 1996). These presynaptic and postsynaptic mechanisms are believed to be linked by retrograde signaling through the NO-cGMP-PKG pathway (Gage et al., 1997; ReyesHarde et al., 1999a,b), and plasticity at Aplysia sensory-motor neuron synapses during classical conditioning also involves ret- 
rograde signaling (Antonov et al., 2003). It is not yet known whether homosynaptic potentiation similarly involves retrograde signaling, but it evidently does not involve the NO-cGMP-PKG pathway (Fig. $7 A, B$ ).

Homosynaptic potentiation at Aplysia sensory-motor neuron synapses, thus, shares components of the mechanisms of a variety of other forms of homosynaptic plasticity including PTP, LTP, and LTD, but does not appear to be identical to any of them. These results support the idea that there is a molecular alphabet of components that can be combined in various ways to create a wide range of different types of plasticity with different functional properties. An implication of this idea is that the different types of plasticity may have evolved in this way to serve different functional purposes. The behavioral function of homosynaptic potentiation in Aplysia is still uncertain, but when the potentiation occurs at the same time as presynaptic facilitation by serotonin, the two types of plasticity interact to create an associative mechanism, activity-dependent enhancement of presynaptic facilitation that is thought to contribute to classical conditioning (Eliot et al., 1994a; Bao et al., 1998; Antonov et al., 2003). Like homosynaptic potentiation, activity-dependent presynaptic facilitation in isolated cell culture can be blocked by presynaptic EGTA, postsynaptic BAPTA, or strong postsynaptic hyperpolarization, but unlike homosynaptic potentiation, it can also be blocked by a presynaptic inhibitor of PKA (Bao et al., 1997, 1998). Thus, activity-dependent presynaptic facilitation appears to combine some of the mechanisms of homosynaptic potentiation with those of presynaptic facilitation (the PKA pathway). A testable prediction of this idea is that activity-dependent presynaptic facilitation may also involve the additional mechanisms of homosynaptic potentiation that we have described, including intracellular $\mathrm{Ca}^{2+}$ release, CamKII, MAP kinase, and possibly AMPA receptor insertion, and that these may in turn contribute to some of the functional properties of classical conditioning in Aplysia.

\section{References}

Angers A, Fioravante D, Chin J, Cleary LJ, Bean AJ, Byrne JH (2002) Serotonin stimulates phosphorylation of Aplysia synapsin and alters its subcellular distribution in sensory neurons. J Neurosci 22:5412-5422.

Antonov I, Antonova I, Minnal A, Hawkins RD (2001) Possible interaction of pre- and postsynaptic mechanisms during classical conditioning in Aplysia. Soc Neurosci Abstr 27:954.15.

Antonov I, Antonova I, Kandel ER, Hawkins RD (2003) Activity-dependent presynaptic facilitation and Hebbian LTP are both required and interact during classical conditioning in Aplysia. Neuron 37:135-147.

Anwyl R, Lee WL, Rowan M (1988) The role of calcium in short-term potentiation in the rat hippocampal slice. Brain Res 459:192-195.

Bao JX, Kandel ER, Hawkins RD (1997) Involvement of pre- and postsynaptic mechanisms in posttetanic potentiation at Aplysia synapses. Science 275:969-973.

Bao JX, Kandel ER, Hawkins RD (1998) Involvement of presynaptic and postsynaptic mechanisms in a cellular analog of classical conditioning at
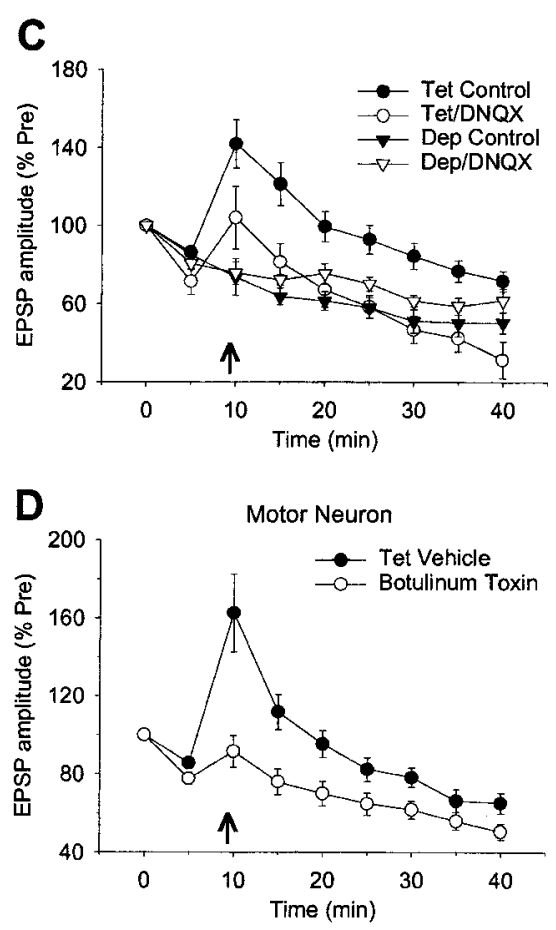

Figure 7. Homosynaptic potentiation does not require NO but may involve AMPA receptor insertion. A, Homosynaptic potena scaver the data from 10 to $40 \mathrm{~min}$. D, Homosynaptic potentiation is also reduced by injection of the light chain of botulinum toxin type $B$ ( $0.5 \mu \mathrm{m}$ in the electrode), which blocks exocytocis, into the motor neuron.

Aplysia sensory-motor neuron synapses in isolated cell culture. J Neurosci $18: 458-466$.

Bashir ZI, Bartolotto ZA, Davies CH, Berretta N, Irving AJ, Seal AJ, Henley JM, Jane DE, Watkins JC, Collingridge GL (1993) Induction of LTP in the hippocampus needs synaptic activation of glutamate metabotropic receptors. Nature 363:347-350.

Bliss TVP, Collingridge GL (1993) A synaptic model of memory: long-term potentiation in hippocampus. Nature 361:31-39.

Bortolotto ZA, Collingridge GL (1993) Characterization of LTP induced by the activation of glutamate metabotropic receptors in area CA1 of the hippocampus. Neuropharmacology 3:1-9.

Boyle MB, Klein M, Smith SJ, Kandel ER (1984) Serotonin increases intracellular $\mathrm{Ca}^{2+}$ transients in voltage-clamped sensory neurons of Aplysia californica. Proc Natl Acad Sci USA 81:7642-7646.

Braha O, Edmonds B, Sacktor T, Kandel ER, Klein M (1993) The contributions of protein kinase $\mathrm{A}$ and protein kinase $\mathrm{C}$ to the actions of 5-HT on the L-type $\mathrm{Ca}^{2+}$ current of the sensory neurons in Aplysia. J Neurosci 13:1839-1851.

Chin J, Angers A, Cleary LJ, Eskin A, Byrne JH (2002) Transforming growth factor $\beta 1$ alters synapsin distribution and modulates synaptic depression in Aplysia. J Neurosci 22:RC220(1-6).

Chitwood RA, Li Q, Glanzman DL (2001) Serotonin facilitates AMPA-type responses in isolated siphon motor neurons of Aplysia in culture. J Physiol (Lond) 534:501-510.

Conrad P, Wu F, Schacher S (1999) Changes in functional glutamate receptors on a postsynaptic neuron accompany formation and maturation of an identified synapse. J Neurobiol 39:237-248.

Creager R, Dunwiddie T, Lynch G (1980) Paired-pulse and frequency facilitation in the CA1 region of the in vitro rat hippocampus. J Physiol (Lond) 299:409-424.

Dale N, Kandel ER (1993) L-glutamate may be the fast excitatory transmitter of Aplysia sensory neurons. Proc Natl Acad Sci USA 90:7163-7167.

DeReimer SA, Kaczmarek LK, Lai Y, McGuiness TL, Greengard P (1984) 
Calcium calmodulin-dependent protein phosphorylation in the nervous system of Aplysia. J Neurosci 4:1618-1625.

Dunwiddie TV, Lynch G (1979) The relationship between extracellular calcium concentrations and the induction of hippocampal long-term potentiation. Brain Res 169:103-110.

Eliot LS, Kandel ER, Siegelbaum SA, Blumeneld H (1993) Imaging terminals of Aplysia sensory neurons demonstrates role of enhanced $\mathrm{Ca}^{2+}$ influx in presynaptic facilitation. Nature 361:634-637.

Eliot LS, Hawkins RD, Kandel ER, Schacher S (1994a) Pairing-specific, activity-dependent presynaptic facilitation at Aplysia sensory-motor neuron synapses in isolated cell culture. J Neurosci 14:368-383.

Eliot LS, Kandel ER, Hawkins RD (1994b) Modulation of spontaneous transmitter release during depression and posttetanic potentiation of Aplysia sensory-motor neuron synapses isolated in culture. J Neurosci 14:3280-3292.

Emptage NJ, Reid CA, Fine A (2001) Calcium stores in hippocampal synaptic boutons mediate short-term plasticity, store-operated $\mathrm{Ca}^{2+}$ entry, and spontaneous transmitter release. Neuron 29:197-208.

English JD, Sweatt JD (1996) Activation of p42 mitogen-activated protein kinase in hippocampal long-term potentiation. J Biol Chem 271:24329-24332.

Gage AT, Reyes M, Stanton PK (1997) Nitric-oxide-guanylyl-cyclasedependent and independent components of multiple forms of long-term synaptic depression. Hippocampus 7:286-295.

Glanzman DL (1994) Postsynaptic regulation of the development and longterm plasticity of Aplysia sensorimotor synapses in cell culture. J Neurobiol 25:666-693.

Greengard P, Valtorta F, Czenik AJ, Benfenati F (1993) Synaptic vesicle phosphoproteins and regulation of synaptic function. Science 259:780-785.

Hawkins RD, Son H, Arancio O (1998) Nitric oxide as a retrograde messenger during long-term potentiation in hippocampus. Prog Brain Res 118:155-172.

Kapur A, Yeckel M, Johnston D (2001) Hippocampal mossy fiber activity evokes $\mathrm{Ca}^{2+}$ release in CA3 pyramidal neurons via a metabotropic glutamate receptor pathway. Neuroscience 107:59-69.

Kononenko N, Hawkins RD (1998) PTP at Aplysia sensory-motor neuron synapses in isolated cell culture does not involve NMDA receptors or nitric oxide signaling. Soc Neurosci Abstr 24:1189.

Kuromi H, Kidokoro Y (2002) Selective replenishment of two vesicle pools depends on the source of $\mathrm{Ca}^{2+}$ at the Drosophila synapse. Neuron 35:333-343.

Lev-Ram V, Makings LR, Keitz PF, Kao JPY, Tsien RY (1995) Long-term depression in cerebellar Purkinje neurons results from coincidence of nitric oxide and depolarization-induced $\mathrm{Ca}^{2+}$ transients. Neuron 15:407-415.

Li Q, Glanzman DL (2002) The role of IP3 receptor-mediated calcium release from postsynaptic intracellular stores in serotonin-induced facilitation of Aplysia sensorimotor synapses. Soc Neurosci Abstr 28:376.8.

Li Q, Villareal G, Glanzman DL (2001) The role of postsynaptic calcium and postsynaptic exocytosis in serotonin-induced facilitation of Aplysia sensorimotor synapses. Soc Neurosci Abstr 27:954.10.

Lin XY, Glanzman DL (1994a) Long-term potentiation of Aplysia sensorimotor synapses in cell culture: regulation by postsynaptic voltage. Proc $\mathrm{R}$ Soc Lond B Biol Sci 255:113-118.

Lin XY, Glanzman DL (1994b) Hebbian induction of long-term potentiation of Aplysia sensorimotor synapses: partial requirement for activation of a NMDA-related receptor. Proc R Soc Lond B Biol Sci 255:215-221.

Malinow R, Malenka RC (2002) AMPA receptor trafficking and synaptic plasticity. Annu Rev Neurosci 25:103-126.

McPherson PS, Kim YK, Valdivia H, Knudson CM, Takekura H, FranziniArmstrong C, Coronado R, Campbell KP (1991) The brain ryanodine receptor: a caffeine-sensitive calcium release channel. Neuron 7:17-25.

Meissner G (1986) Ryanodine activation and inhibition of the $\mathrm{Ca}^{2+}$ release channel of sarcoplasmic reticulum. J Biol Chem 261:6300-6306.

Montarolo PG, Goelet P, Castellucci VF, Morgan J, Kandel ER, Schacher S
(1986) A critical period of macromolecular synthesis in long-term heterosynaptic facilitation in Aplysia. Science 234:1249-1254.

Montarolo PG, Kandel ER, Schacher S (1988) Long-term heterosynaptic inhibition in Aplysia. Nature 333:171-174.

Mulkeen D, Anwyl R, Rowan M (1988) The effects of external calcium on long-term potentiation in the rat hippocampal slice. Brain Res 447:234-238.

Nakanishi K, Zhang F, Baxter DA, Eskin A, Byrne JH (1997) Role of calcium-calmodulin-dependent protein kinase II in modulation of sensorimotor synapses in Aplysia. J Neurophysiol 78:409-416.

Narita K, Akita T, Hachisuka J, Huang SM, Ochi K, Kuba K (2000) Functional coupling of $\mathrm{Ca}^{2+}$ channels to ryanodine receptors at presynaptic terminals. Amplication of exocytosis and plasticity. J Gen Physiol 115:519-532

O'Dell TJ, Kandel ER, Grant SG (1991) Long-term potentiation in the hippocampus is blocked by tyrosine kinase inhibitors. Nature 353:558-560.

Perez Y, Morin F, Lacaille JC (2001) A Hebbian form of long-term potentiation dependent on mGluR1a in hippocampal inhibitory interneurons. Proc Natl Acad Sci USA 98:9401-9406.

Purcell AL, Carew TJ (2001) Modulation of excitability in Aplysia tail sensory neurons by tyrosine kinases. J Neurophysiol 85:2398-2411.

Rayport SG, Schacher S (1986) Synaptic plasticity in vitro: cell culture of identified Aplysia neurons mediating short-term habituation and sensitization. J Neurosci 6:759-763.

Reyes M, Stanton PK (1996) Induction of hippocampal long-term depression requires release of $\mathrm{Ca}^{2+}$ from separate presynaptic and postsynaptic intracellular stores. J Neurosci 16:5951-5960.

Reyes-Harde M, Empson R, Potter BVL, Galione A, Stanton PK (1999a) Evidence of a role for cyclic ADP-ribose in long-term synaptic depression in hippocampus. Proc Natl Acad Sci USA 96:4061-4066.

Reyes-Harde M, Potter BVL, Galione A, Stanton PK (1999b) Induction of hippocampal LTD requires nitric oxide-stimulated PKG activity and $\mathrm{Ca}^{2+}$ release from cyclic ADP-ribose-sensitive stores. J Neurophysiol 82:1569-1576.

Rosenthal J (1969) Post-tetanic potentiation at the neuromuscular junction of the frog. J Physiol (Lond) 203:121-133.

Schacher S (1985) Differential synapse formation and neurite outgrowth at two branches of the metacerebral cell of Aplysia in dissociated cell culture. J Neurosci 5:2028-2034.

Schacher S, Montarolo PG, Kandel ER (1990) Selective short- and longterm effects of serotonin, small cardioactive peptide, and tetanic stimulation on sensorimotor synapses of Aplysia in culture. J Neurosci 10:3286-3294.

Schacher S, Wu F, Sun ZY (1997) Pathway-specific synaptic plasticity: activity-dependent enhancement and suppression of long-term heterosynaptic facilitation at converging inputs on a single target. J Neurosci 17:597-606.

Schaffhausen JH, Fischer TM, Carew TJ (2001) Contribution of postsynaptic $\mathrm{Ca}^{2+}$ to the induction of posttetanic potentiation in the neural circuit for siphon-withdrawal in Aplysia. J Neurosci 21:1739-1749.

Stanton PK, Gage AT (1996) Distinct synaptic loci of $\mathrm{Ca}^{2+} /$ calmodulindependent protein kinase II necessary for long-term potentiation and depression. J Neurophysiol 76:2097-2101.

Unni VK, Siegelbaum SA (2001) The role of presynaptic ryanodinesensitive calcium stores in long-term depression. Soc Neurosci Abstr 27:15.11.

Wilsch VW, Behnisch T, Jager T, Reymann KG, Balschun D (1998) When are class I metabotropic glutamate receptors necessary for long-term potentiation? J Neurosci 18:6071-6080.

Woodhall G, Gee CE, Robitaille R, Lacaille JC (1999) Membrane potential and intracellular $\mathrm{Ca}^{2+}$ oscillation activated by mGluRs in hippocampal stratum oriens/alveus interneurons. J Neurophysiol 81:371-382.

Yeckel MF, Kapur A, Johnston D (1999) Multiple forms of LTP in hippocampal CA3 neurons use a common postsynaptic mechanism. Nat Neurosci 2:625-633.

Zucker RS, Regehr WG (2002) Short-term synaptic plasticity. Annu Rev Physiol 64:355-405. 